Yellow rain

\section{Waiting for data}

A group of representatives of the United States government has been visiting ten European capitals during the past three weeks, presenting the evidence behind allegations by Mr Alexander Haigh, the US Secretary of State, that Russian-produced mycotoxins have been dropped on civilians in Kampuchea (Nature, 1 October, p.327). The representatives - who asked that they and their affiliations should not be identified - have discussed the evidence with government scientists and the press. But the evidence remains chiefly circumstantial and the release of information before the scientific evidence has been properly presented has done little to clarify whether the allegations are correct.

The mycotoxins concerned are from the tricothecene group, produced by the Fusarium fungi. The circumstantial evidence for their use in Laos, Kampuchea and Afghanistan consists largely of the descriptions of symptoms experienced by civilians within a few hours of the dropping of "yellow rain" from low-flying aircraft. According to the anonymous speakers at the US Embassy in London last week, the progressive symptoms of vomiting, skin blisters, haemorrhaging of mucous membranes and death were observed by journalists, doctors and refugees from these countries and, it was stated, were not consistent with "traditional" chemical warfare agents. Moreover, according to the speakers, the climatic conditions in Laos (from where the detailed evidence was drawn) are not conducive to the natural production of these toxins by fungi.

Only one sample of vegetation affected by yellow rain, taken from Laos by a person "trained in chemical warfare", has so far been analysed, and the results of that investigation - carried out by Dr C. J. Mirocha of the University of Minnesota have not yet been accepted for publication. Dr Mirocha confirmed that three toxins, T2, nivalenol and deoxynivalenol, had been identified, and agreed with the statement that the concentrations of the last two were about twenty times the amounts observed in contaminated vegetation in other parts of the world. But he disagreed that the climate of Laos would prohibit toxin production, although he felt that other fungi would prevent Fusarium from producing the toxins. He felt that until his results had been published, they could not be properly discussed.

Several questions remain unanswered. None of the descriptions of observed symptoms were attributed to specific observers so that it is not possible to ascertain how objective that evidence is. The symptoms produced by mycotoxin poisoning vary greatly from species to species, according to Dr D. Paterson at the Central Veterinary Laboratory in
Weybridge, who has investigated the effects of mycotoxins on cattle. It is not obvious, therefore, that the symptoms described can definitely be attributed to mycotoxins. When asked what type of vegetation had been sampled, the government scientist replied that it was " a small bush",

Other samples are being analysed, and - as the rainy season in Laos is soon to end - it is expected that "yellow rain" may soon be falling again. But the combination of unattributed evidence, premature and incomplete discussion of scientific evidence and vested interest may have combined to defeat the purpose of the European expert tour. Philip Campbell

\section{European Community research Savings on defence?}

\section{Brussels}

European Commissioner Karl-Heinz Narjes has set the cat among the pigeons by suggesting that EEC countries should cooperate on defence and military research.

This was just one of the ideas put forward in a policy paper on industrial innovation which looks at how Europe's flagging competitiveness could be improved by action at EEC level. Although only cautiously mooted by Narjes, the suggestion has led to a heated debate among the European Commissioners. Not only is cooperation on military matters excluded from the Treaty of Rome and therefore not a matter for EEC, but certain member states, notably Ireland, are already disturbed that discussions by EEC's foreign affairs ministers should include defence questions. Ireland is not a member of NATO and has neutral status.

Narjes, however, feels that the time is right to debate the advantages of sharing the costs of military research. France and the United Kingdom devote about 50 per cent of their public sector research and development budgets to military research which frequently provides valuable commercial spin-offs. France under Mitterrand is certainly more amenable to wider cooperation on defence matters and in the rest of the Community the need to keep public sector budgets pared to a minimum will surely make the idea attractive.

Another suggestion Narjes raises in the paper is to link the Community's research with the activities of the European Space Agency. The new horizons this could open up were considered in a report by European parliamentarian, André Turcat (see Nature 1 October, p.330).

In the main, though, the paper concentrates on more down-to-earth prospects: more innovation-orientated spending by the social and regional funds, improving access to risk capital, bringing together European companies to pool research in new technologies, and improving the incentives for investment in new technology. The European Commission has already organized a meeting of representatives from information technologies to identify the areas in which basic and noncompetitive research could take place.

A chief target of the paper is the restrictive nature of the national public supply markets. These absorb some 10 per cent of the gross domestic product and are under the immediate control of governments which, claims the commission, only favour national suppliers. These public markets are invariably in technologically rapidly evolving sectors (telecommunications, information technology, energy, transport and education) and where the successful can seldom take advantages of the large European market.

Narjes's paper will be followed by a second with more detailed suggestions that could be ready for the next European Council in London on 26 November. There the so-called May 30th mandate, which requires that the Community should move away from the heavy emphasis on agricultural spending and put more effort into industrial and social affairs, will be discussed.

Jasper Becker

\section{French science budget}

\section{More for all}

Is a budget increase of - on the face of it - nearly a third for research and development, 1,800 new posts in universities and a further 630 in research agencies a vision of some glorious year of the 21st century? No, it will be France in 1982, if budget plans announced last week are put into effect.

Research and innovation are clearly a central plank in the Mitterrand government's philosophy of boom or bust; and provided inflation does not waste the rewards, French scientists seem likely to benefit greatly in the next few years.

In 1982, there should be a 20 per cent increase (less inflation) in the civil research budget. The universities will get only a 16 per cent cash increase, but many new posts, 400 of them from 1 January. Of the research agency posts, 348 will be at the prestigious Centre Nationale de la Recherche Scientifique - an increase of nearly 5 per cent on its total research staff. The university posts will be principally "assistants", junior appointments to absorb unemployed graduates of the "troisième cycle" (effectively post-docs) and rejuvenate ageing departments.

According to Jean-Pierre Chevènement, minister for research and technology, the exact allocation of the increased research budget will not be decided until after the National Colloquium on Science and Technology in Paris in mid-January. However, the division of the budget among research agencies already makes clear some rather remarkable priorities.

For example, despite the new French commitment to nuclear power (strongly championed by Chevenement), the lowest 
percentage increase in research budget accrues to the Commissariat à l'Energie Atomique (CEA) (18 per cent) while the highest goes to the Commissariat à l'Energie Solaire (COMES) (50 per cent). Nevertheless, CEA has a budget of 5,200 million francs ( $£ 520$ million) and COMES only $\mathbf{3 0 0}$ million francs.

Some of these increases must, however, be qualified by a French budgetary distinction between "crédits de paiement" (money actually received in 1982) and "crédits d'autorisation" (money which can be committed, as in ordering a piece of equipment, but not necessarily spent).

It is in terms of these crédits d'autorisation that there will be an increase of 29 per cent (to 25,000 million francs from 19,000 million francs). In crédits de paiement, the increase is only 15 per cent. Thus in his budget Chevènement is gambling heavily - as is all of France - on future economic success. Of what he offers to research, about half is not yet in the government's coffers. Robert Walgate

\section{UK research funding}

\section{Cutting problems}

The British Science and Engineering Research Council is alarmed that the quality of research in some outstanding science departments is being jeopardized by the reluctance of universities to be sufficiently selective in deciding where to make economies. The council's anxiety has apparently increased since the University Grants Committee informed individual universities last July of the cut in their incomes and student numbers over the next three years. Although guidance on student quotas for different subject areas was fairly specific, the council considers that advice on where to save money was too vague. It is disturbed by evidence that universities are tending to make unselective cuts.

The worry is that universities are endangering the concept of a well-found laboratory on which the dual support system for funding university research depends. The system demands that universities provide well-equipped laboratories run by tenured staff while the research councils award grants to individuals for specific research projects. The Science and Engineering Research Council intends to continue awarding grants on the merit of proposals provided that they come from laboratories with an adequate research base. But it says that if universities make cuts across the board, facilities in many departments may be so weakened that it would be unable to support their work.

That apparently has already happened on occasion in recent years. In such cases, the council has made grants conditional on the university providing the funds for basic equipment. By March 1980, the position was such that the Advisory Board for the Research Councils set up a committee to recommend what should be done. The committee has now resumed its investigations after postponing its report when the latest cuts to the universities became known.

Sir Alec Merrison, chairman of the committee, believes that it should report by the end of the year so as to provide universities with guidance on how to reorganize while minimizing the damage to research.

Judy Redfearn

\section{US engineering graduates Firms step in}

\section{Washington}

Increasingly concerned at growing bottlenecks in the production of engineers by US universities and colleges, as well as the decreasing willingness of the federal government to provide financial assistance to overcome this problem, private companies are taking matters into their own hands.

Two weeks ago, member companies of the American Electronics Association, computer and data processing equipment manufacturers who have been among the hardest hit by current shortages in qualified manpower, agreed that over the next five years they would set aside two per cent of their research and development budget to assist university and college computer science and engineering departments.

This decision could produce an extra $\$ 50$ million to help support engineering education, and follows the announcement in September that the Exxon Education Foundation is to launch a five-year, $\$ 15$-million programme of assistance to engineering schools and faculty members across the country. The money will be shared among 66 colleges, including both private and state universities. Under the programme, 100 doctoral candidates will receive an average of $\$ 50,000$ over the three years of their studies. An additional $\$ 20,000$ will be provided to 100 departments of engineering, earth sciences and computer science specifically to help subsidize higher salaries for young teaching faculty members .

Although the Exxon Foundation's grant programme is said to be the largest ever undertaken by a corporate entity, it is not unique. IBM, for example, has awarded 278 graduate and predoctoral fellowships in mathematics, science and engineering in the past three years, and is making 180 grants of $\$ 25,000$ each to university departments between 1980 and 1984 - a total of $\$ 4.5$ million.

Furthermore, the private sector is so concerned that efforts to revitalize the US technological base could founder on a shortage of adequately trained engineers that Exxon and IBM have joined with six other major corporations (AT\&T, du Pont, General Electric, General Motors, General Telephone and Electronics and Union Carbide) to sponsor a two-year programme in Washington under the umbrella of the American Society for Engineering Education to consider how the federal government might help to solve the shortage of engineering college faculty.

Although pay differentials are the most widely-quoted cause for the current shortage, other factors from federal regulation of research to the obsolesence of teaching equipment - have contributed to the crisis.

There is no shortage of potential students. News of the heavy demands for engineering graduates, often being offered starting salaries of $\$ 25,000$ a year or more, has filtered quickly down into the schools, and some universities and colleges say that they are now having to limit the intake of engineering undergraduates.

According to figures being prepared by the National Science Foundation, however, private industry employers are now having "major difficulties" in filling their requirements for computer, electrical/electronic and chemical engineers. Employers had reported "some difficulties" in recruiting mechanical, industrial, petroleum and mining engineers, but said that demand and supply were in balance for aerospace engineers, while there was evidence of an oversupply of civil engineers.

Nor is it only the private sector that is worried. General Robert T. Marsh, commander of the US Air Force Systems Command is concerned that a shortage of highly qualified scientists and engineers is threatening the US defence capability.

The Reagan Administration has already advertised its concern for the general shortage of engineering graduates in both the private and military sectors. It insists that this problem should, where possible, be solved through the maximum involvement of private companies.

Some of these efforts, however, may already be beginning to backfire. Dr Ivan Bennett, dean of New York University Medical Center, has told the advisory committee to the director of the National Institutes of Health that although recent changes in the tax law make it more attractive for companies to donate secondhand research equipment to universities, some corporate leaders had told him that the value of this incentive was virtually cancelled out by the accelerated depreciation now allowed on such equipment. David Dickson

\section{Genetic engineering Biogen digs in}

\section{Zurich}

Within a period of days Biogen, one of the first biotechnology companies, has opened an American counterpart to its Geneva laboratory, appointed one of last year's Nobel prizewinners as chairman of its board of directors and secured $\$ 20$ million of additional financial backing. Biogen seems bent on being among the ten 